\title{
How we should tailor the nodal staging for various types of lung cancer?
}

\author{
Shun-ichi Watanabe \\ Department of Thoracic Surgery, National Cancer Center Hospital, Tokyo, Japan \\ Correspondence to: Shun-ichi Watanabe, MD. Department of Thoracic Surgery, National Cancer Center Hospital, Tsukiji 5-1-1, Tokyo 104-0045, \\ Japan. Email: syuwatan@ncc.go.jp. \\ Provenance and Peer Review: This article was commissioned and reviewed by the Guest Section Editor Zhuoqi Jia (Thoracic Department, the First \\ Affiliated Hospital of Xi'an Jiaotong University, Xi'an, China), Journal of Thoracic Disease. \\ Comment on: Moulla Y, Gradistanac T, Wittekind C, et al. Predictive risk factors for lymph node metastasis in patients with resected non-small cell \\ lung cancer: a case control study. J Cardiothorac Surg 2019;14:11.
}

Submitted Nov 16, 2019. Accepted for publication Jan 26, 2020.

doi: $10.21037 /$ jtd.2020.02.22

View this article at: http://dx.doi.org/10.21037/jtd.2020.02.22

In 1951, Cahan (1) reported that pneumonectomy with mediastinal nodal dissection could be a curative surgery for primary lung cancer. He then suggested that lobectomy with mediastinal nodal dissection, so called "radical lobectomy" should be a standard surgical treatment in 1960 (2). This technique was accepted worldwide and has been a standard surgical treatment for non-small cell lung cancer (NSCLC). The figures of mediastinal nodal dissection described in his report in 1951 were identical with our current procedure of mediastinal dissection (1). In a next few decades, reevaluation of nodal status during thoracotomy procedure for NSCLC had evolved into a more meticulous and sophisticated assessment of disease extent. Central to this is an assessment of lymph node metastasis at the both hilum and mediastinum levels. This technique, termed "systematic nodal dissection" (SND) by the IASLC, has been recognized as an important element of surgical staging (3), simply because the microscopic nodal status is considered to be the strongest prognostic factor for NSCLC among many clinicopathological factors. Microscopic evaluation of removed lymph nodes offers the most reliable information as for prognosis of NSCLC patients. Precise identification of lymph node involvement leads us to selection of the patients requiring adjuvant therapy and suggests us the precise prognosis of each patient with NSCLC.

In the article "Predictive risk factors for lymph node metastasis in patients with resected non-small cell lung cancer: a case control study" recently published by Dr.
Yusef Moulla et al. (4) in Fournal of Cardiothoracic Surgery shows how to make precise assessment of the nodal status in NSCLC patients. They analyzed prospectivelyestablished database of 204 consecutive NSCLC patients who underwent thoracotomy. Among them, lymph node involvement was found in $38.2 \%$. Central localization of the primary tumor (OR: 2.6, 95\% CI: $1.3-5.1$ ) and size of primary tumor $>3 \mathrm{~cm}$ (OR: 2.5 , 95\% CI: $1.3-4.4$ ) were significant predictive factors for lymph node metastasis. Microscopic intratumoral invasion of the lymph vessels (L1-status) (OR: 17.3, 95\% CI: 5.1-58.4) and the central localization of the primary tumor (OR: 2.8, 95\% CI: 1.4-5.8) were significant predictive factors for nodal metastasis. Two significant predictive factors for nodal involvement were identified in small-sized tumors $\leq 3 \mathrm{~cm}$ : central localization of primary tumor (OR: $19.4,95 \%$ CI: 2.1-186.4) and L1-status (OR: 43.9, 95\% CI: 3.6-529.4). They suggested that precise assessment of the lymph node status before and during thoracotomy is essential for largersized $(>3 \mathrm{~cm})$ and centrally located tumors. Moreover, microscopic L1-status is the most significant risk factor for nodal involvement in NSCLC patients. They also suggested that adjuvant chemotherapy might be considered after pulmonary resection based on microscopic L1-status regardless of nodal involvement.

The authors are to be congratulated on their successful results. Surgeons have recognized that the nodal status during thoracotomy is not always as diagnosed by 
preoperative assessment. Meta-analyses have shown that the sensitivity and specificity for CT in nodal status are ranged $52 \%$ to $79 \%$ and $69 \%$ to $78 \%$, respectively $(5,6)$. Positron emission tomography (PET) has considered to be more accurate investigation as for nodal status, however, the sensitivity and specificity are ranged just $79 \%$ to $85 \%$ and $90 \%$ to $91 \%$, respectively (7). Therefore the preoperative nodal evaluation by CT or PET is not reliable enough, especially in patients with microscopic nodal involvement. Actually, $60 \%$ of cN1 patients diagnosed by CT was microscopically changed to be $\mathrm{N} 2$ disease after SND in adenocarcinoma patients (8). Even in small-sized $(\leq 2 \mathrm{~cm})$ NSCLC patients, more than $20 \%$ of patients show nodal metastasis $(9,10)$. This is why SND is recognized to be an essential component of pathological staging.

Recently, however, the incidence of small-sized NSCLC is increasing dramatically, therefore the strategy of mediastinal dissection for NSCLC has changed. The lobespecific pathways of nodal metastasis have retrospectively analyzed and reported by many thoracic surgeons. Asamura et al. (11) and Okada et al. (12) suggested that the tumors located within right upper lobe and left upper division segment often involve the superior mediastinal nodes, but rarely involve the subcarinal nodes. Okada et al. reported that the tumor within lower lobe seldom involve the superior mediastinal nodes without involve the hilar or subcarinal lymph nodes. Based on the results of lobe-specific patterns of nodal metastatic pathway, the preoperative assessment of the $\mathrm{N}$ status and strategy of mediastinal dissection have been changing in c-stage I, II lung cancer. Since the incidence of detecting early NSCLC is increasing, the intraoperative extent of mediastinal dissection should be tailored by the location and size of primary tumor, histological type, and consolidation/tumor ratio $(\mathrm{C} / \mathrm{T}$ ratio) on thin-slice CT in each tumor. The tailored extent of nodal dissection was termed "lobe-specific SND" by ESTS guidelines (13). In the "lobe-specific SND", the "key nodes," which should be microscopically checked during thoracotomy by the frozen section examination, was found in each lobe (14).

However, regarding the tumor other than GGO lesion or small-sized lung cancer, we must take care not to underestimate the nodal status pre- or intra-operatively. Wang et al. (15) reported that the negative predictive value for mediastinal involvement by using both PET and CT was 0.94 in T1 tumors and 0.89 in T2 tumors. Lee et al. (16) reported that the centrally-located tumors had a significantly higher incidence of microscopic mediastinal involvement compared to peripherally-located tumors, 21.6 vs. $2.9 \%$ in clinical stage I patients evaluated by both PET and CT. Abovementioned paper described by Dr._Moulla (4) suggested the hint of selecting the candidate of preoperative meticulous staging using endobronchial ultrasoundguided transbronchial needle aspiration (EBUS-TBNA) or postoperative pathological staging by SND, especially for larger-sized $(>3 \mathrm{~cm})$ tumors, central located tumors and pathologic L-1 status.

\section{Acknowledgments}

Funding: None.

\section{Footnote}

Conflicts of Interest: The author has completed the ICMJE uniform disclosure form (available at http://dx.doi. org/10.21037/jtd.2020.02.22). The author has no conflicts of interest to declare.

Ethical Statement: The author is accountable for all aspects of the work in ensuring that questions related to the accuracy or integrity of any part of the work are appropriately investigated and resolved.

Open Access Statement: This is an Open Access article distributed in accordance with the Creative Commons Attribution-NonCommercial-NoDerivs 4.0 International License (CC BY-NC-ND 4.0), which permits the noncommercial replication and distribution of the article with the strict proviso that no changes or edits are made and the original work is properly cited (including links to both the formal publication through the relevant DOI and the license). See: https://creativecommons.org/licenses/by-nc-nd/4.0/.

\section{References}

1. Cahan WG, Watson WL, Pool JL. Radical pneumonectomy. J Thorac Surg 1951;22:449-73.

2. Cahan WG. Radical lobectomy. J Thorac Cardiovasc Surg 1960;39:555-72.

3. Goldstraw P. Report on the International workshop on intrathoracic staging, London, October 1996. Lung Cancer 1997;18:107-11.

4. Moulla Y, Gradistanac T, Wittekind C, et al. Predictive risk factors for lymph node metastasis in patients with resected non-small cell lung cancer: a case control study. J 
Cardiothorac Surg 2019;14:11.

5. Webb WR, Gatsonis C, Zerhouni EA, et al. CT and MR imaging in staging non-small cell bronchogenic carcinoma: report of the Radiologic Diagnostic Oncology Group. Radiology 1991;178:705-13.

6. Dales RE, Stark RM, Raman S. Computed tomography to stage lung cancer. Approaching a controversy using metaanalysis. Am Rev Respir Dis 1990;141:1096-101.

7. Gould MK, Kuschner WG, Rydzak CE, et al. Test performance of positron emission tomography and computed tomography for mediastinal staging in patients with non-small-cell lung cancer: a meta-analysis. Ann Intern Med 2003;139:879-92.

8. Watanabe S, Asamura H, Suzuki K, et al. Problems in diagnosis and surgical management of clinical N1 nonsmall cell lung cancer. Ann Thorac Surg 2005;79:1682-5.

9. Watanabe S, Oda M, Go T, et al. Should mediastinal nodal dissection be routinely undertaken in patients with peripheral small-sized ( $2 \mathrm{~cm}$ or less) lung cancer? Retrospective analysis of 225 patients. Eur J Cardiothorac Surg 2001;20:1007-11.

10. Takizawa T, Terashima M, Koike T, et al. Mediastinal lymph node metastasis in patients with clinical stage I peripheral non-small-cell lung cancer. J Thorac Cardiovasc
Surg 1997;113:248-52.

11. Asamura H, Nakayama H, Kondo H, et al. Lobe-specific extent of systematic lymph node dissection for non-small cell lung carcinomas according to a retrospective study of metastasis and prognosis. J Thorac Cardiovasc Surg 1999;117:1102-11.

12. Okada M, Tsubota N, Yoshimura M, et al. Proposal for reasonable mediastinal lymphadenectomy in bronchogenic carcinomas: role of subcarinal nodes in selective dissection. J Thorac Cardiovasc Surg 1998;116:949-53.

13. Lardinois D, De Leyn $P$, Van Schil P, et al. ESTS guidelines for intraoperative lymph node staging in non-small cell lung cancer. Eur J Cardiothorac Surg 2006;30:787-92.

14. Watanabe S, Asamura H. Lymph node dissection for lung cancer: significance, strategy, and technique. J Thorac Oncol 2009;4:652-7.

15. Wang J, Welch K, Wang L, et al. Negative predictive value of positron emission tomography and computed tomography for stage T1-2N0 non-small-cell lung cancer: a meta-analysis. Clin Lung Cancer 2012;13:81-9.

16. Lee PC, Port JL, Korst RJ, et al. Risk factors for occult mediastinal metastases in clinical stage I non-small cell lung cancer. Ann Thorac Surg 2007;84:177-81.
Cite this article as: Watanabe SI. How we should tailor the nodal staging for various types of lung cancer? J Thorac Dis 2020;12(7):3890-3892. doi: 10.21037/jtd.2020.02.22 